\title{
Pengembangan Portal Tugas Akhir Program Studi Teknik Informatika Universitas Sam Ratulangi
}

\author{
Ilhammad Maulana Ani, Steven R. Sentinuwo dan Xaverius B. N. Najoan. \\ Program Studi Teknik Informatika, Fakultas Teknik, Universitas Sam Ratulangi \\ Email : ilhamani9@gmail.com, steven@unsrat.ac.id, xnajoan@unsrat.ac.id
}

\begin{abstract}
Pengembagan Portal Web dimaksudkan untuk menyimpan data judul tugas akhir dan menyimpan hasil asistensi tugas akhir mahasiswa. Dengan web ini memudahkan dosen untuk melihat daftar mahasiwa bimbingan tugas akhir. Metodologi yang digunakan dalam melakukan pengembangan web adalah metode Rapid Application Development merupakan pengembangan aplikasi cepat yang merupakan versi adaptasi dari model waterfall. Pengembangan sistem mengunakan PHP framework CodeIgniter sebagai bahasa pemrograman dan MySQL sebagai basis data. Dengan ini telah menghasilkan aplikasi untuk menyimpan data tugas akhir mahasiswa dan dapat memudahkan dalam pencarian data tugas akhir dan dosen dalam melihat data mahasiswa bimbingan.
\end{abstract}

Kata Kunci : MySQL, Framework Codeigniter, Rapid Applcation Development, Tugas Akhir, Web.

\section{Pendahuluan}

$\mathrm{W}$ eb cepat sekali populer di lingkungan pengguna internet, karena memberikan kemudahan pada pengguna internet untuk melakukan penelusuran dan pencarian informasi. Internet menjadi sarana yang sangat popular saat ini karena internet menyediakan berbagai informasi yang tidak terbatas.

Web sistem informasi untuk lembaga pendidikan digunakan sebagai sarana untuk memberikan, selain itu digunakan sebagai melakukan kegiatan-kegiatan perkuliahan, penyimpanan data proses perkuliahan dan sebagainya.

Portal Web Program Studi Informatika sedang dalam tahap pengembangan, sudah ada beberapa fitur diantaranya penyimpanan data-data mahasiswa dan dosen Program Studi Informatika.

Saat ini dalam melakukan penyimpanan dan pencarian judul tugas akhir, data tugas akhir maupun proses penyimpanan hasil asistensi tugas akhir masih dalam bentuk hardcopy (arsip fisik atau dokumen tercetak), dengan banyaknya mahasiswa yang akan dibimbing bisa menyulitkan Dosen pembimbing untuk mengingat judul maupun hasil asistensi Mahasiswa bimbingan.

Aplikasi website Sistem Informasi Portal Web Program Studi diantaranya penyimpanan data-data tugas akhir dan penyimpanan hasil asistensi tugas akhir ini diharapkan bisa mempermudah proses penyimpanan dokumentasi dan mempercepat proses pencarian data mahasiswa yang sedang membuat tugas akhir dan serta dalam melakukan pemantauan perkembangan tugas akhir.

Dengan adanya Web ini diharapkan bisa memperlancar serta memudakan proses dalam melakukan penyimpanan data Judul Tugas akhir, dokumen SK dan penyimpanan hasil asistensi secara online.

\section{LANDASAN TEORI}

\section{A. Sistem Informasi}

Sistem informasi adalah suatu sistem di dalam suatu organisasi yang mempertemukan kebutuhan pengolahan transaksi harian yang mendukung fungsi operasi organisasi yang bersifat manajerial dengan kegiatan strategi dari suatu organisasi untuk dapat menyediakan kepadapihak luar tertentu dengan laporan- laporan yang diperlukan, Tata (2004).

\section{B. Website}

Website atau situs juga dapat diartikan sebagai kumpulan halaman yang menampilkan informasi data teks, data gambar diam atau gerak, data animasi, suara, video dan atau gabungan dari semuanya, baik yang bersifat statis maupun dinamis yang membentuksatu rangkaian bangunan yang saling terkait dimana masing-masing dihubungkan dengan jaringan-jaringan halaman (hyperlink).

\section{PHP Framework Codeigniter}

CodeIgniter adalah salah satu dari sekian banyak framework PHP yang tersedia secara gratis. Pengembang CodeIgniter adalah seorang musisi rock-n-roll bernama Rick Ellis dari EllisLab (http://www.ellislab.com). Tujuan dari pembuatan framework CodeIgniter ini menurut user manualnya adalah untuk menghasilkan framework yang akan dapat digunakan untuk pengembangan proyek pembuatan website secara lebih cepat dibandingkan dengan pembuatan website dengan cara koding secara manual. yang dibutuhkan.

\section{UML (Unified Modeling Language)}

UML (Unified Modeling Language) adalah bahasa pemodelan untuk sistem atau perangkat lunak yang berparadigma berorientasi objek. Pemodelan sesungguhnya digunakan untuk penyederhanaan permasalahan- 
E-journal Teknik Informatika, Volume 7, No. 1.(2016), ISSN : 2301-8364

permasalahan yang kompleks sedemikian rupa sehingga lebih mudah dipelajari dan dipaham. Nugroho(2010)

Berdasarkan pendapat yang dikemukakan di atas dapat ditarik kesimpulan bahwa UML adalah sebuah bahasa yang berdasarkan grafik atau gambar untuk menvisualisasikan, menspesifikasikan, membangun dan pendokumentasian dari sebuah sistem pengembangan perangkat lunak berbasis Objek (Object Oriented programming).

\section{Use Case Diagram}

Use-case diagram merupakan model UML yang digunakan untuk menggambarkan requirement fungsional yang diharapkan dari sebuah sistem. Use-case diagram menekankan pada "siapa" melakukan "apa" dalam lingkungan sistem perangkat lunak akan dibangun.

\section{E. Rapid Applcation Develpment}

RAD atau pengembangan aplikasi cepat adalah pendekatan berorientasi objek untuk pengembangan sistem yang meliputi metode pengembangan serta perangkat lunak (Kendall, 2008). Kendal dan Kendall (2007) melihat RAD sebagai metodologi pengembangan sistem yang berusaha untuk mengatasi perubahan persyaratan kebutuhan user dan merekomendasikan RAD untuk mengembangkan aplikasi berbasis web. RAD merupakan model proses perangkat lunak yang menekankan pada daur pengembangan hidup yang singkat.

Gambar model proses $R A D$ dapat dilihat pada gamabar 1 .

Tahapan RAD terdiri dari 3 fase, yaitu:

\section{Requirements Planning (Perencanaan Persyaratan)}

Pada tahap ini, user dan analis melakukan semacam pertemuan untuk melakukan identifikasi tujuan dari aplikasi atau sistem dan melakukan identifikasi kebutuhan informasi untuk mencapai tujuan. Pada tahap ini hal terpenting adalah adanya keterlibatan dari kedua belah pihak, bukan hanya sekedar persetujuan akan proposal yang sudah dibuat.

\section{Design Workshop}

Pada tahap ini adalah melakukan proses desain dan melakukan perbaikan-perbaikan apabila masih terdapat ketidaksesuaian desain antara user dan analis. Untuk tahap ini maka keaktifan user yang terlibat sangat menentukan untuk mencapai tujuan, karena user bisa langsung memberikan komentar apabila terdapat ketidaksesuaian pada desain. Biasanya, user dan analis berkumpul menjadi satu dan duduk di meja melingkar dimana masing-masing orang bisa melihat satu dengan yang lain tanpa ada halangan.

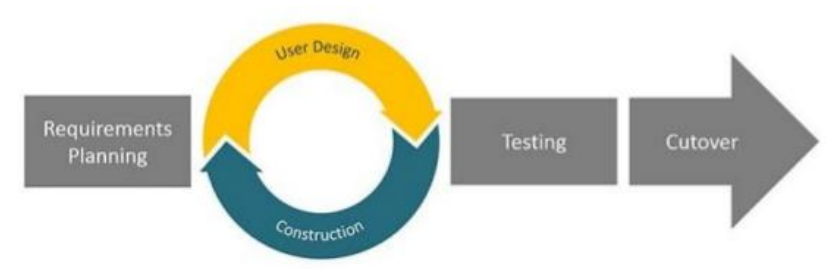

\section{Implementation (Penerapan)}

Setelah desain dari sistem yang akan dibuat sudah disetujui baik itu oleh user dan Analyst, maka pada tahap ini programmer mengembangkan desain menjadi suatu program. Setelah program selesai baik itu sebagian maupun secara keseluruhan, maka dilakukan proses pengujian terhadap program tersebut apakah terdapat kesalahan atau tidak sebelum diaplikasikan pada suatu organisasi. Pada saat ini maka user bisa memberikan tanggapan akan sistem yang sudah dibuat serta persetujuan mengenai sistem tersebut. Adapun hal terpenting adalah bahwa keterlibatan user sangat diperlukan agar sistem yang dikembangkan dapat memberikan kepuasan kepada user dan di samping itu, sistem yang lama tidak perlu dijalankan secara paralel dengan sistem yang baru.

\section{Metodologi Penelitian}

\section{A. Analisis Kebutuhan}

Langkah analisis persyaratan bertujuan untuk melakukan perencanaan dan penjadwalan perancangan sistem serta mengidentifikasi kebutuhan pengguna dan spesifikasi system, sehingga sistem yang akan dibuat akan sesuai dengan yang dibutuhkan oleh pengguna.

\section{Tabel 1. Spesifikasi Pengguna}

\begin{tabular}{|c|l|l|}
\hline $\begin{array}{c}\text { Pengg } \\
\text { una }\end{array}$ & Peran & \multicolumn{1}{|c|}{ Tanggung Jawab } \\
\hline Admin & Admin & $\begin{array}{l}\text { Aktor yang menggunakan Sistem } \\
\text { Informasi Portal Web Program Studi } \\
\text { Teknik Informatika Unsrat untuk } \\
\text { mengelola data-data Mahasiswa dan } \\
\text { Dosen. }\end{array}$ \\
\hline Maha & User & $\begin{array}{l}\text { Aktor yang menggunakan Sistem } \\
\text { Informasi Portal Web Program Studi } \\
\text { Teknik Informatika Unsrat untuk } \\
\text { menambahkan data SK dan Asistensi } \\
\text { Tugas Akhir. }\end{array}$ \\
\hline Dosen & User & $\begin{array}{l}\text { Aktor yang menggunakan Sistem } \\
\text { Informasi Portal Web Program Studi } \\
\text { Teknik Informatika Unsrat untuk } \\
\text { Melihat data mahasiswa bimbingan } \\
\text { hasil asistensi tugas akhir. }\end{array}$ \\
\hline
\end{tabular}




\section{B. Desain Modelling}

Langkah desain modelling bertujuan untuk melakukan perancangan sistem melalui analisa yang telah dilakukan sebelumnya. Hasil dari langkah ini berupa spesifikasi desain, rancangan database, dan rancangan interface.

\section{Use Case Diagram}

Use case diagram dirancang untuk menunjukkan secara umum fungsi dan tanggung jawab masing-masing aktor sistem dalam Sistem Informasi yang akan dirancang. Use case diagram dari Sistem Informasi ini dapat dilihat pada gambar 2.

\section{DFD (Data Flow Diagram)}

Data Flow Diagram (DFD) dirancang untuk menunjukkan arah aliran data yang terjadi dalam Sistem Informasi yang akan dirancang. Data yang dibutuhkan dalam Sistem Informasi yang akan dirancang adalah data mahasiswa sehingga diagram DFD ini menunjukkan arah aliran data mahasiswa di dalam sistem ini. DFD dari Sistem Informasi ini terbagi atas dua level yaitu DFD Level 0 yang dapat dilihat pada gambar 3 .

DFD level 0 menunjukkan arah aliran data mahasiswa dari sudut pandang sistem secara keseluruhan. Data mengalir saat admin memasukan data mahasiswa ke sistem dan mahasiswa mengisi data ke sistem, kemudian data mengalir ke admin dan dosen. DFD Level 0 dapat dilihat pad gambar 3

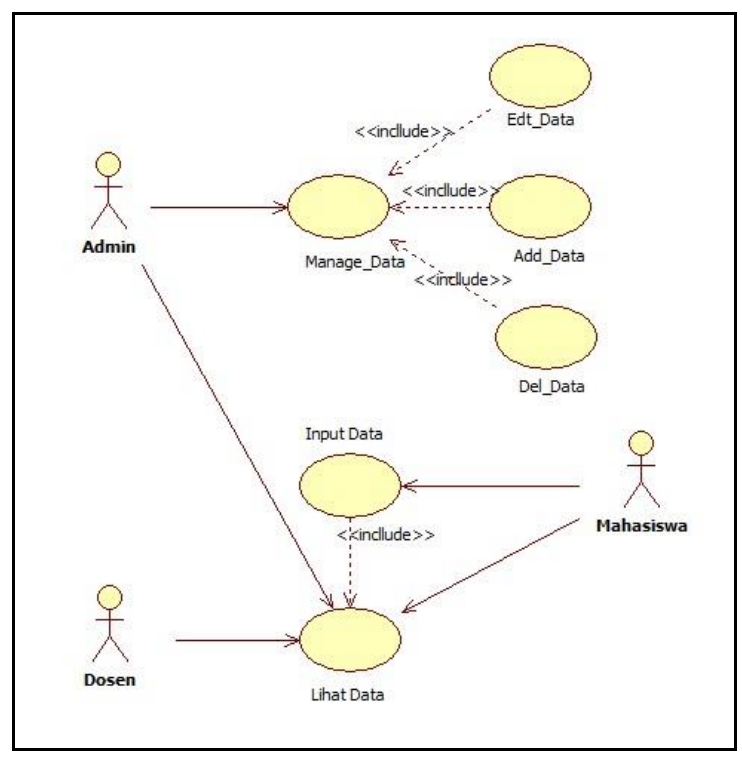

Gambar 2. Use Case Diagram

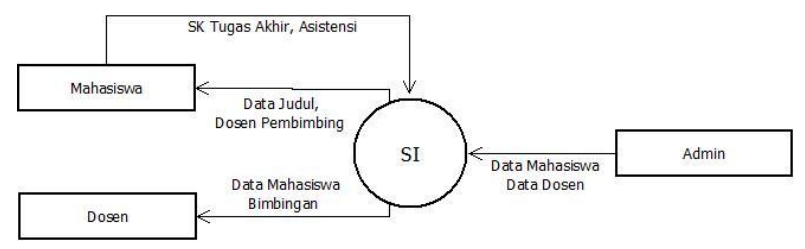

Gambar 3. DFD Level 0
DFD level 1 menunjukkan arah aliran dari data admin ke data mahasiswa dan data mahasiswa dari sudut pandang sistem secara bertahap. Data mengalir saat admin memasukan data ke mahasiswa dan dosen dan kemudian terjadi proses penginputan data. DFD level 1 dapat dilihat pada gambar 4.

DFD level 2 menunjukan arah aliran data dari proses admin menginput data mahasiswa dapat dilihat pada gambar 5 , beranda mahasiswa yang menunjukan proses arah aliran data mahasiswa ketika menginput hasil asistensi dan data SK tugas akhir dapat dilihat pada gambar 7 dan beranda dosen yang menunjukan aliran data mahasiswa bimbingan dapat dilihat ada gambar 6 .

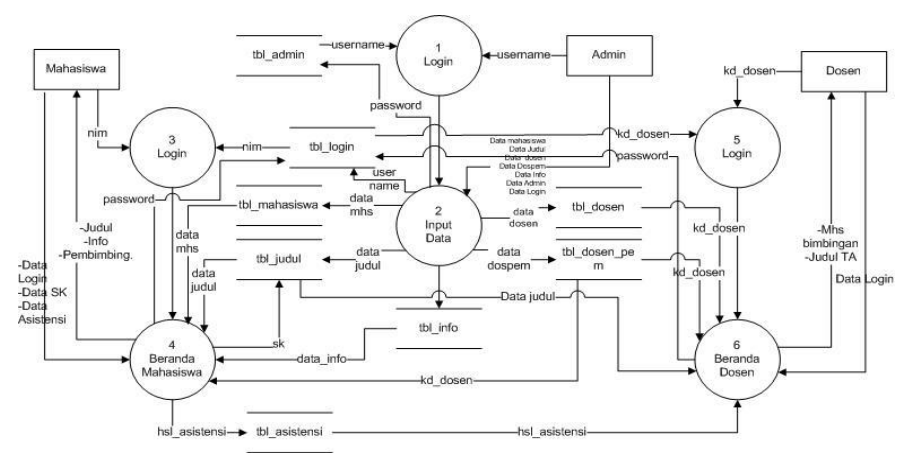

Gambar 4. DFD Level 1

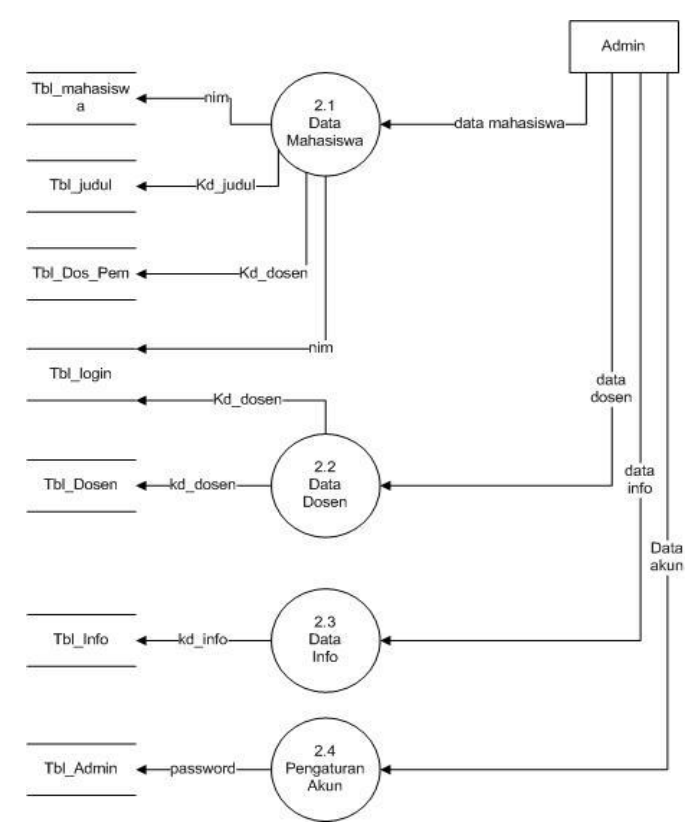

Gambar 5. DFD Level 2 Input Data

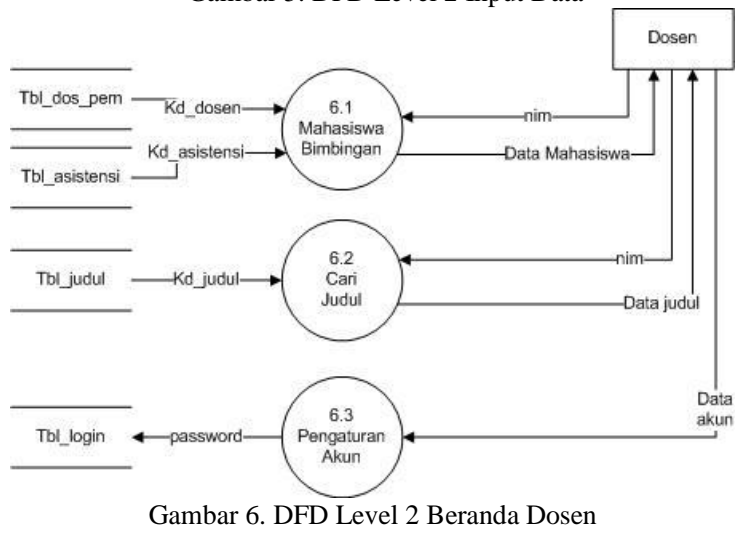


E-journal Teknik Informatika, Volume 7, No. 1.(2016), ISSN : 2301-8364

\section{Rancangan Database}

Database dari Sistem Informasi ini sendiri dirancang menggunakan aplikasi MySQL. Tabeltabel yang ada di dalam rancangan database tersebut, nama-nama atribut yang ada dalam masing-masing tabel, tipe data masing-masing atribut dan panjang tipe datanya. Dapat dilihat pada tabel 2 sampai tabel 9.

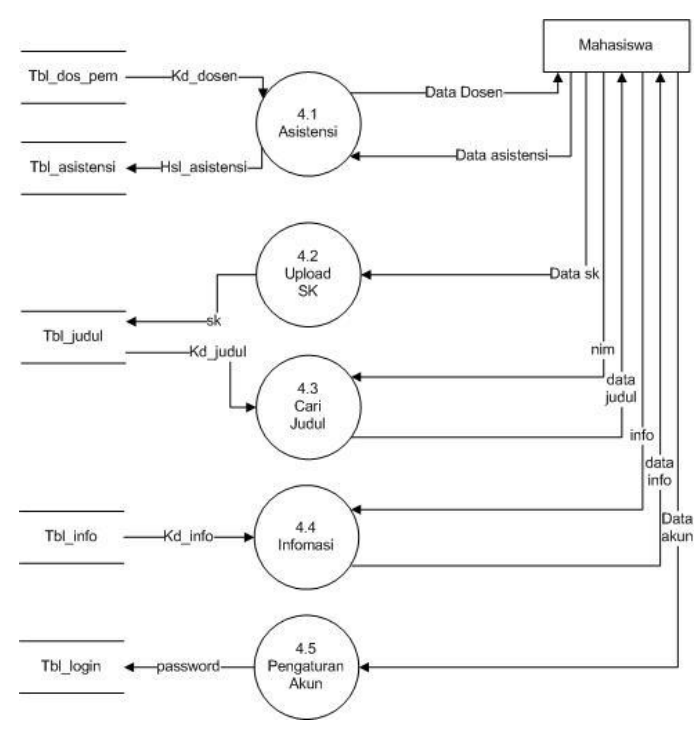

Gambar 7. DFD Leel 2 Beranda Mahasiswa

Tabel 2. Admin

\begin{tabular}{|l|l|c|}
\hline \multicolumn{1}{|c|}{$\begin{array}{c}\text { Nama } \\
\text { Atribut }\end{array}$} & \multicolumn{1}{|c|}{ Tipe Data } & $\begin{array}{c}\text { Panjang Tipe } \\
\text { Data }\end{array}$ \\
\hline username & Vachar & 50 \\
\hline password & Varchar & 50 \\
\hline nama_lengkap & Varchar & 100 \\
\hline
\end{tabular}

Tabel 3. Asistensi

\begin{tabular}{|l|l|c|}
\hline \multicolumn{1}{|c|}{$\begin{array}{c}\text { Nama } \\
\text { Atribut }\end{array}$} & \multicolumn{1}{|c|}{ Tipe Data } & $\begin{array}{c}\text { Panjang Tipe } \\
\text { Data }\end{array}$ \\
\hline nim & Integer & 20 \\
\hline kd_dosen & Varchar & 20 \\
\hline hsl_asistensi & Text & \\
\hline tgl_asistensi & Varchar & 10 \\
\hline
\end{tabular}

Tabel 4. Dosen

\begin{tabular}{|l|l|c|}
\hline \multicolumn{1}{|c|}{$\begin{array}{c}\text { Nama } \\
\text { Atribut }\end{array}$} & \multicolumn{1}{c|}{ Tipe Data } & $\begin{array}{c}\text { Panjang Tipe } \\
\text { Data }\end{array}$ \\
\hline kd_dosen & Varchar & 20 \\
\hline nip & Varchar & 50 \\
\hline nama_dosen & Varchar & 50 \\
\hline
\end{tabular}

Tabel 5. Dosen Pembimbing

\begin{tabular}{|l|l|c|}
\hline \multicolumn{1}{|c|}{$\begin{array}{c}\text { Nama } \\
\text { Atribut }\end{array}$} & \multicolumn{1}{c|}{ Tipe Data } & $\begin{array}{c}\text { Panjang Tipe } \\
\text { Data }\end{array}$ \\
\hline nim & Varchar & 20 \\
\hline kd_dosen & Varchar & 20 \\
\hline kd_dosen2 & Varchar & 20 \\
\hline
\end{tabular}

\section{Konstruksi}

Langkah konstruksi bertujuan untuk membangun sistem berdasarkan hasil desain modelling yang telah didapatkan. Berdasarkan hasil desain modelling, dilakukan konstruksi berupa coding atau kodifikasi program. Kodifikasi merupakan proses penulisan source code atau kode-kode sumber yang akan membangun sistem dari segi interface sistem dan logika atau proses dari sistem itu sendiri. Kodekode sumber yang digunakan dalam tahap kodifikasi ini antara lain kode sumber HTML sebagai perancangan antarmuka atau interface sistem, serta kode sumber PHP sebagai bahasa pemrograman yang membentuk logika atau proses dari sistem.

\section{Testing / Evaluasi}

Tahap terakhir yang dilakukan adalah tahap evaluasi. Tahap evaluasi dilakukan dengan menguji coba hasil perancangan sistem yang telah dibangun pada tahap penerapan metode. Tahap uji coba yang dilakukan yaitu uji coba sistem berdasarkan use case diagram, uji coba tipe-tipe data dalam sistem dengan melakukan proses input data menggunakan data.

Tabel 6. Info

\begin{tabular}{|l|l|c|}
\hline \multicolumn{1}{|c|}{$\begin{array}{c}\text { Nama } \\
\text { Atribut }\end{array}$} & \multicolumn{1}{|c|}{ Tipe Data } & $\begin{array}{c}\text { Panjang Tipe } \\
\text { Data }\end{array}$ \\
\hline kd_info & Integer & 10 \\
\hline judul & Varchar & 200 \\
\hline waktu_post & Varchar & 3 \\
\hline isi & Text & \\
\hline
\end{tabular}

Tabel 7. Judul

\begin{tabular}{|l|l|c|}
\hline \multicolumn{1}{|c|}{ Nama Atribut } & \multicolumn{1}{|c|}{ Tipe Data } & $\begin{array}{c}\text { Panjang } \\
\text { Tipe Data }\end{array}$ \\
\hline kd_judul & Integer & 10 \\
\hline judul & Varchar & 250 \\
\hline nim & Varchar & 20 \\
\hline sk1 & Varchar & 100 \\
\hline sk2 & Varchar & 100 \\
\hline sk3 & Varchar & 100 \\
\hline jurnal & Varchar & 100 \\
\hline abstrak & Text & 250 \\
\hline tgl_upload & Varchar & 250 \\
\hline
\end{tabular}

Tabel 8. Mahasiswa

\begin{tabular}{|l|l|c|}
\hline \multicolumn{1}{|c|}{ Nama Atribut } & \multicolumn{1}{c|}{ Tipe Data } & $\begin{array}{c}\text { Panjang } \\
\text { Tipe Data }\end{array}$ \\
\hline nim & Varchar & 20 \\
\hline nama_mahasiswa & Varchar & 100 \\
\hline angkatan & Int & 5 \\
\hline
\end{tabular}

Tabel 9. Login

\begin{tabular}{|l|l|c|}
\hline $\begin{array}{c}\text { Nama } \\
\text { Atribut }\end{array}$ & Tipe Data & $\begin{array}{c}\text { Panjang Tipe } \\
\text { Data }\end{array}$ \\
\hline username & Varchar & 50 \\
\hline password & Varchar & 75 \\
\hline stts & Varchar & 10 \\
\hline
\end{tabular}


E-journal Teknik Informatika, Volume 7, No. 1.(2016), ISSN : 2301-8364

\section{HASIL}

Setelah melakukan semua tahapan sesuai dengan metodologi Rapid Application Develpment, pada tahap ini akan dijelaskan hasil dari penelitian yang dilakukan berdasarkan tujuan awal yaitu membuat suatu sistem informasi aplikasi portal web.

\section{A. Halaman Login}

Halaman login merupakan halaman awal yang ditampilkan saat user mengakses halaman sistem. Halaman login digunakan untuk membatasi hak akses pengguna sistem karena setiap pengguna memiliki hak akses masingmasing. Tampilan halaman login dapat dilihat pada Gambar 8.

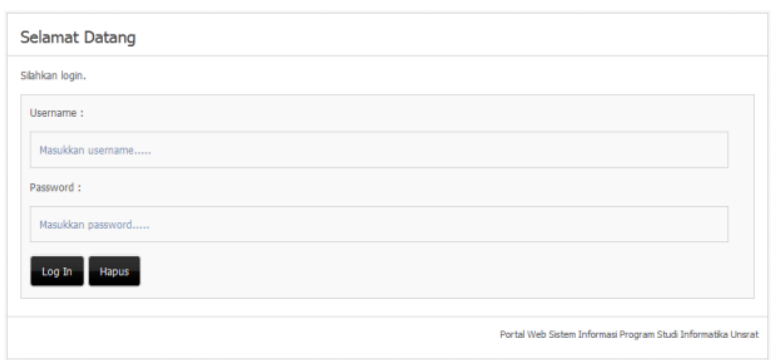

Gambar 8. Tampilan halaman login

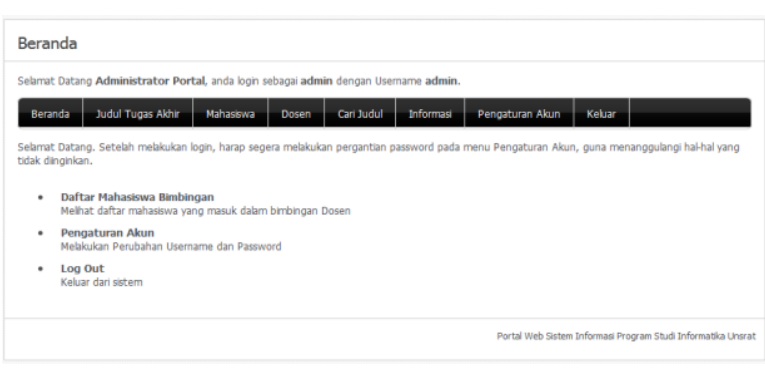

Gambar 9. Tampilan Halaman Admin

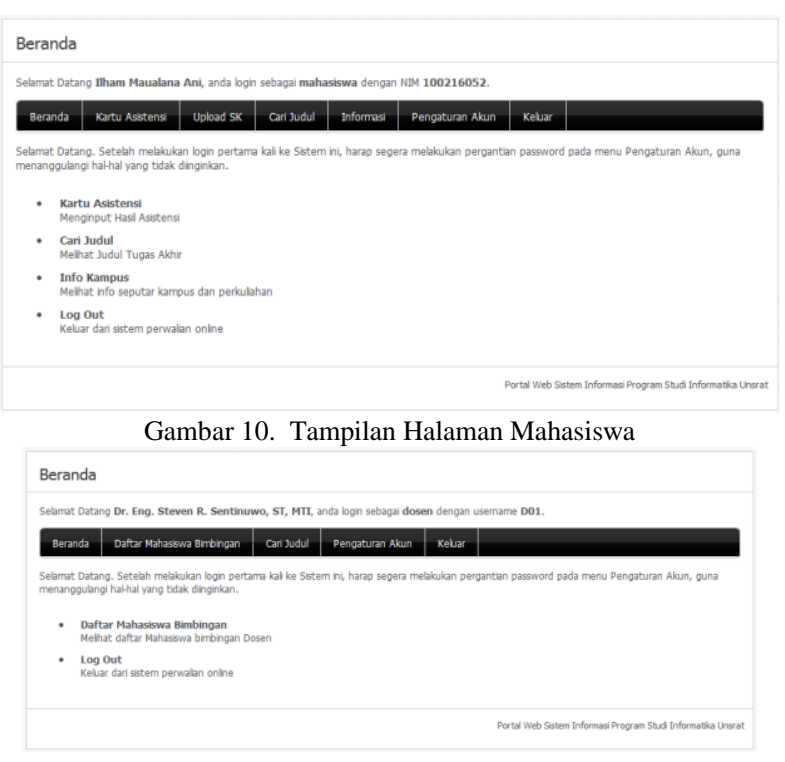

Gambar 11. Tampilan Halaman Dosen

\section{B. Halaman admin}

Halaman admin memiliki akses untuk menambahkan data tugas akhir mahasiswa dan dosen, serta dapat melihat semua data mahasiswa. Tampilan halaman admin pendaftaran dapat dilihat pada Gambar 9.

\section{Halaman Mahasiswa}

Halaman mahasiswa memiliki hak akses untuk menginput data SK dan hasil asistensi tugas akhir. Tampilan halaman mahasiswa dapat dilihat pada Gambar 10.

\section{Halaman Dosen}

Halaman dosen memiliki hak akses untuk melihat daftar mahasiswa bimbingan dan dapat melihat data-data mahasiswa bimbingan. Tampilan halaman dosen dapat dilihat pada Gambar 11 .

\section{PENUTUP}

\section{A. Kesimpulan}

Dengan ini telah dirancangan dan dibangun aplikasi sistem informasi dari pengembangan Portal Web Program Studi Teknik Informatika Universitas Sam Ratulangi dalam menyelesaikan masalah penyimpanan data judul tugas akhir mahasiswa di Program Studi Informatika Unsrat.

Kesimpulan yang dapat diberikan dari perancangan pengembangan portal web ini adalah sebagai berikut:

- Menghasilkan sebuah aplikasi untuk menyimpan data tugas akhir mahasiswa Program Studi Informatika Unsrat dengan menggunakan bahasa bahasa pemrograman PHP 5.3.8 dan database mySQL.

- Pengembangan portal web ini dibuat dengan menggunakan PHP framework CodeIgniter V.3.0.0 .

- Menghasilkan aplikasi yang dapat menyimpan dan mencari data-data tugas akhir mahasiswa serta memudahkan Dosen dalam melihat daftar mahasiswa bimbingan tugas akhir di Program Studi Informatika Unsrat.

\section{B. Saran}

Apabila untuk kedepannya ada yang ingin mengembangkan penelitian ini lebih lanjut, disarankan untuk membuat versi mobile-based application dari Sistem Informasi ini. 


\section{DAFTAR PUSTAKA}

[1] Janner. 2009, Rekayasa Web, Andi, Medan.

[2] Kendall. 2007, System Analysis and Design $7^{\text {th }}$ ed, Pearson Prentice Hall.

[3] Kendall. 2008, Analisis \& Perancangan sistem, Indeks, Jakarta.

[4] Kosdianto. 2003, Perancangan dan pembuatan aplikasi web untuk pemantauan Kemajuan tugas akhir mahasiswa di jurusan Teknik Informatika, Universitas Kristen Petra, Surabaya.

[5] Murdick, Ross. 1993, Perancangan dan Pembangunan Sistem Informasi, Andi, Yogyakarta.

[6] Pressman. 2010, Rekayasa Perangkat Lunak, Andy, Indonesia

[7] Putra. 2015, Sistem Informasi Admisi Program Pascasarjana Unsrat berbasis web, Universitas Sam Ratulangi, Manado.

[8] Schach. 2008, Object Oriented Software Engineering 8th Ed, McGrawHill.

[9] Tata, Sutabri. 2004, Analisa Sistem Informasi, Andi Offset, Yogyakarta.

[10] Tata, Sutabri. 2005, Sistem Informasi Manajemen, Andi Offset,Yogyakarta.

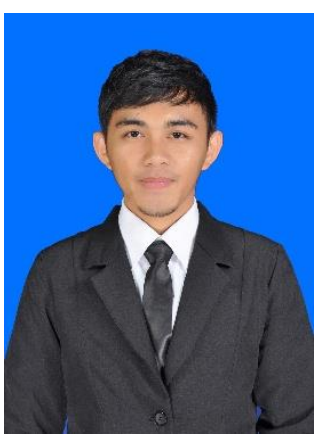

Penulis bernama lengkap Ilhammad Maulana Ani, anak pertama dari tiga orang bersaudara. Lahir di Gogagoman, pada tanggal 9 September 1992. Dengan alamat tempat tinggal sekarang di jl. Sea, lrg.Perum PDK, Malalayang 1.

Sekolah pertama tempat belajar adalah Taman KanakKanak Al-huda, Kotamobagu. Selanjutnya, melanjutkan ke SD Negeri 1 Gogagoman, Kotamobagu. Selanjutnya, melanjutkan ke MTs Negeri Kotamobagu, Kotamobagu. Dan menyelesaikan sekolah tingkat atas di SMK Cokroaminoto, Kotamobagu.

Pada tahun 2010, Penulis melanjutkan studi di Fakultas Teknik, Jurusan Elektro, Program Studi Informatika Universitas Sam Ratulangi Manado. Selama kuliah, Penulis tergabung dalam organisasi Himpunan Mahasiswa Elektro (HME) dan Badan Tazkir Fakultas Teknik UNSRAT. 